\title{
Green Technology Design Approach for Liveable Park of Tasik Biru Kundang, Malaysia
}

\author{
Rijal Saffuan ${ }^{1}$, Junaidah Ariffin ${ }^{2}$, Zamreen Amin ${ }^{1}$ \\ ${ }^{1}$ Faculty of Architecture, Planning and Surveying, ${ }^{2}$ Faculty of Civil Engineering, \\ Universiti Teknologi MARA, 40000 Shah Alam, Malaysia \\ rijalsaffuan@gmail.com
}

\begin{abstract}
Green Technology designapproach is anew solution thatmustbeapplicable to preserveanature and reduce the pollution. Thereare so muchinnovation could be used to in the development of the park to reduce the electricity use, eco-friendly and livable for the community. This paperaimsto exemplify an effortbyagroup ofstudents, throughmulti-professional inputs, indesigning for a city facility that can add more towards a livable city. The results of the approach are multidisciplinary design that includes the idea from multiprofessional in making a livable park for community surroundings Tasik Biru Kundang, Kuang, Selangor, Malaysia.
\end{abstract}

Keywords: Green technology; Livability; Multi professional; Design approach

eISSN 2514-751X @ 2018 . The Authors. Published for AMER ABRA cE-Bs by e-International Publishing House, Ltd., UK. This is an open access article under the CC BY-NC-ND license (http://creativecommons.org/licenses/bync-nd/4.0/). Peer-review under responsibility of AMER (Association of Malaysian Environment-Behaviour Researchers), ABRA (Association of Behavioural Researchers on Asians) and cE-Bs (Centre for EnvironmentBehaviour Studies), Faculty of Architecture, Planning \& Surveying, Universiti Teknologi MARA, Malaysia.

DOI: https://doi.org/10.21834/aje-bs.v3i7.262 


\subsection{Introduction}

Parks play many non-obvious roles in constructing a society. If we truly believe in a society of equals, we must have a few minimum conditions for equality. Equality is not about the equality of income, butequality of dignity as a member of society and equality for the pursuit of human development and happiness. Higher income people always have access to nature at beach houses, lake cabins, mountain chalets, on vacations - or in urban settings at golf courses or large gardens. Parks allow the rest of society that contact (Enrique Peñalosa Londono, 2001). Parks and other public pedestrian spaces are some of those few critical elements that make societies a bit equal. Park should be planned to fulfil the society needs so that upper class people and lower class people could be together using the facilities. Parks and other public pedestrian spaces are some of those few critical elements that make societies a bit equal. Planning for better pedestrian space should encourage upper class people to walk is important to prevent them from using car that should increase carbon emissions. Unique natural resources such as coastlines, riverbanks, mountains, should never be private and exclusive, particularly in urban and suburban settings. These are God's gift to mankind. Excluding anybody from access to them should be deemed illegitimate and not democratic.

\subsection{Planning Park for Liveable Cities}

Livable Cities the place is suitable to live and habitable for the people. The world's most livable cities is an informal name given to any list of cities as they rank on a reputable annual survey of living conditions. Two examples are the Mercer Quality of Living Survey and the Economist Intelligence Unit's Global Liveability Report. Livability rankings are designed for use by employers assigning hardship allowances as part of job relocation. There have been numerous arguments over the expansion of livability rankings for other purposes. However, the annual city rankings attract extensive media coverage, are a popular topic of discussion and have attracted the attention of even the White House (Economic Intelligent Unit, 2012).

The Economist Intelligence Unit's most recent livability report shows cities in Canada, Australia, Austria, Finland and New Zealand as the ideal destinations, thanks to a widespread availability of goods and services, low personal risk, and an effective infrastructure. It does not take into account climate or the cost of living as a factor in 'livability.' The August 2012 EIU Report placed Melbourne, Australia as the most livable city in the world, with Vienna, Austria taking second place, followed by Vancouver, Canada, unchanged from the top three the previous year. Other Canadian cities also ranked highly in the survey, with Toronto holding the 4th position, and Calgary tied with Adelaide at 5th. Two other Australian cities, Sydney at 7 th and Perth at 9th, were ranked among the top ten.

Table 1 shows the livability ranking scores based on the livability survey made by Economic Intelligent Unit, London focusing on five areas: stability, healthcare, culture and environment, education, and infrastructure.

According to the Enrique Peñalosa Londono, (2001) former Mayor of Bogota City in his Keynote Address at the Urban Parks Institute's "Great Parks/Great Cities" Conference, July 30, 2001, "The importance of pedestrian public spaces cannot be measured. We cannot prove mathematically that wider sidewalks, pedestrian streets, more or better parks make 
people happier, much less measure how much happier. However if we reflect, most things that are important in life cannot be measured either: Friendship, beauty, love and loyalty are examples. Parks and other pedestrian places are essential to a city's happiness".

Table 1: Ranking Score based on Livability Survey by Economic Intelligent Unit, London

\begin{tabular}{|c|c|c|c|}
\hline Rank & City & Country & Livability \\
\hline 1 & Melbourne & Australia & 97.5 \\
\hline 2 & Vienna & Austria & 97.4 \\
\hline 3 & Vancouver & Canada & 97.3 \\
\hline 4 & Toronto & Canada & 97.2 \\
\hline 5 & Calgary & Canada & 96.6 \\
\hline 6 & Adelaide & Australia & 96.6 \\
\hline 7 & Sydney & Australia & 96.1 \\
\hline 8 & Helsinki & Finland & 96.0 \\
\hline 9 & Perth & Australia & 95.9 \\
\hline 10 & Auckland & New Zealand & 95.7 \\
\hline
\end{tabular}

Note: Livability 2012 (100=ideal)

Park is a part of cities where human need to have contact with nature. Since it is belongs to the society, the park must be planned well to fulfill the society needs. Our live is depend on the earth survival in many life support elements such as supplies of waters, productive agriculture, industry, forest product, fisheries and many more. A life in the cities is a part of our life. We dream great cities without pollution, healthy condition and adequate facilities that could support our live. For a Great Cities, planning for the park is important for the cities to be more livable (Rijal S. et. al, 2010).

Life is depending on the earth survival in many life support elements such as supplies of waters, productive agriculture, industry, forest product, fisheries and many more. A life in the cities is a part of the life. We dream great cities without pollution, healthy condition and adequate facilities that could support lifetime. For a Great Cities, planning for the park is important for the cities to be more livable. According to the Enrique Peñalosa Londono, former Mayor of Bogota City in his Keynote Address at the Urban Parks Institute's "Great Parks/Great Cities" Conference, July 30, 2001, "The importance of pedestrian public spaces cannot be measured, we cannot prove mathematically that wider sidewalks, pedestrian streets, more or better parks make people happier, much less measure how much happier. However if 35 we reflect, most things that are important in life cannot be measured either: Friendship, beauty, love and loyalty are examples. Parks and other pedestrian places are essential to a city's happiness".

Third World cities are still growing at astonishing high rates. Most will more than double their built area during the next 50 years. By 2015, there will be 22 mega-cities of more than 10 million inhabitants in the Third World. The world's environmental sustainability and quality of life will depend to a large extent of what is done there during the next few years. Yet Third World cities pressed with everyday urgencies are not being particularly creative. There is still time to 
think different, in high density but more pedestrian friendly cities, with countless exclusively pedestrian streets and park areas representing up to $40 \%$ of the city. Perhaps a city that is neither suburban, nor 39 urban in the traditional sense is still possible there. There could be cities with as much public space for children as for cars. The backbone of the alternative city model would have to be pedestrian streets, sidewalks and parks, supported by excellent public transport.

\section{Green Technology Design Approach}

Green Technology is the most effective innovation to be use for the development of park. The liveable park should apply the applications of the products and equipment and systems used to conserve the natural environment resources, which minimizes and reduces the negative impact of human activities. It was also could help to minimize degradation to the environment. The applications of green technology are also had zero or low green house gases (GHG) emissions. It is safe for uses and promotes healthy and improved environment for all form of life. The term technology is referred to the application for practical purposes. It is cover a continuously expanding a group of method and material, from techniques for generating energy to non-toxic cleaning product.

\section{The Design Idea}

The idea of the design practice comes from student competition organised by Nexus of Science and Technology Student Association (NEXSTEC). The students which get involved in this competition comes from multidisciplinary professional such as planner, architecture, landscape architecture, civil engineering, mechanical engineering, applied science and health science. The student involved in this project has given a task to make a sustainable design of the park using green technology innovation for people who live in surrounding of Tasik Biru Kundang, Kuang, Selangor, Malaysia. Tasik Biru Kundang is famous for jet-skiing activities, but it is having very serious pollution problem. The existing development on the lake itself does not fit for people who live near the places for recreational activities. The project was funded by the higher learning institution and community leaders. It also involved public participation to promote better recreation facilities for community and also chances for the student to get involved in community linkages project.

\section{The Design Approach}

The project started with brainstorming of the idea. The student works hard with a limited time given with provided facilities. The brainstorming must be a critical part that used to combine all the idea from various discipline to design a facilities for the people that achieve the goal of sustainability of green technology using in the park. All students play their part in representing their professional. The group leader plays important roles to get multiprofessional inputs, in designing for a park facility. The inputs should be in line of the goal which is to provide sustainable green technology facilities for the residents.

The first part of brainstorming is the scope identifying. The built environment students share same scope of work in designing with their disciplines roles including site inventory and analysis, accessibility analysis and social survey. The engineering students has their own work 
perspective which is making soil structure analysis, water quality analysis, transportation survey, engineering based system and also contribute to the new innovation of green technology. The applied science students and health science act as health advisor in contributing to the idea, educated to the people, health improvement, material using and new innovation of green technologybased on the expertise. (Rijal S. et. al, 2010). The idea was collected by in the brainstorming to making a design that achieve goal of sustainability and providing good facilities for the people.

In the analysis stages, site visit is important to collecting data for the design and research. In multidisciplinary design, the students or player may learn new thing among themselves about to conduct an analysis based on their discipline. Soil structure test and water analysis test been done by the engineers to make sure the quality of water is safe for people and soil structure is good for building construction. Built environment students play their roles in site inventory and socioeconomic survey. After the site visit, the designing stage needs collaboration of built environmentstudent to do their part with the help of engineering students, applied science and health sciences. The design must overcome issue and problem that have been identified in the analysis stages.

In a real practice, we should get involved other discipline as well because only the engineers know their part. Same as other discipline in applied science such as environmental technology, bio composite, plantation and forensic discipline, they knows their part better than planners, architect, and landscape architect. As a support, health, education and safety will comes later to enhance the proposal of other discipline by adding their idea in making the proposal benefit people. (Rijal S. et. al, 2011). At first, the design of concept plan and master plan must be completed. Then, the design must be transfers to physical model and 3 dimensional models.

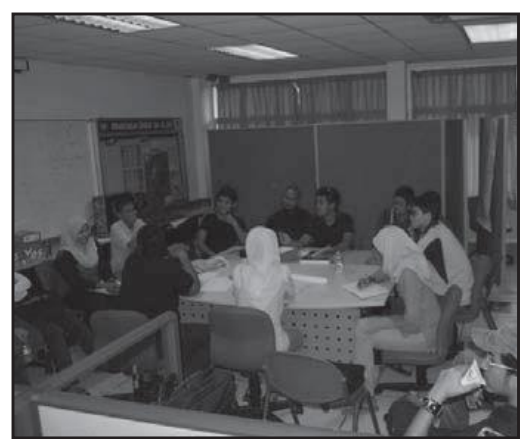

(a)

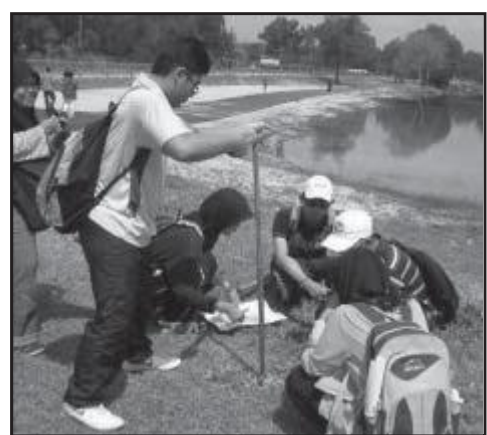

(b)

Figure 1: (a) Brainstorming Session before the Design Stages; (b) Soil Structure Test made by Civil Engineers

The concept plan and master plan must have green technology and sustainability elements. Sustainability needs to be at the heart of everything we do. This leads to a high priority to green technology development and at the same time it will educate the people 
about global warming awareness. In other words, by encouraging renewable will generate a better result in the future. Therefore, it must be in line with goal is to achieve the best outcomes for designing Master Plan for Tasik Biru Kundang, Kuang Selangor, Malaysia. This concept plan is an integrated lake park which use green technology as a major component whereby supporting sustainable development for future proof of the site area. (Rijal S. et. all, 2010).

The strategy concept designs included the elements of sustainable, health and environmental will be implement and focused in every structure design of the recreational lake park. There are three basic activities which are active, semi-active and passive with an adaption of every design strategy that will be developed in this concept plan. Selected elements activities which promote clean energy and power efficiency are the most important subject to support the theme of this concept. A recreational lake park that will benefit to all group of ages in terms of healthcare and an environmental protection to the surrounding area. (Rijal S. et. al, 2010).

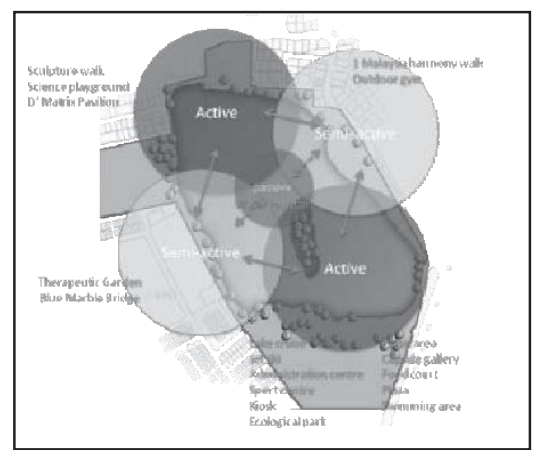

(a)

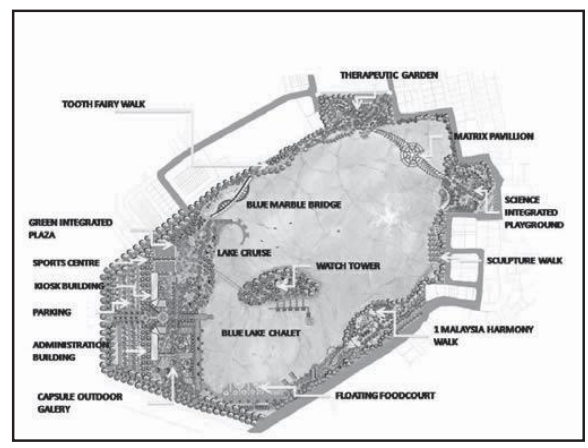

(b)

Figure 2: (a) Concept Plan for Tasik Biru Kundang, Kuang, Selangor; (b) Master Plan for Tasik Biru Kundang, Kuang, Selangor

\begin{tabular}{|c|c|c|}
\hline Civil Engineers & $\begin{array}{l}\text { Geostone Wnils } \\
\text { Bridge }\end{array}$ & $\begin{array}{l}\text { Project A } \\
\text { - Rekench Documentation } \\
\text { - Design (Several Discussion } \\
\text { with Teain) }\end{array}$ \\
\hline $\begin{array}{l}\text { Mechanicul } \\
\text { Engineers }\end{array}$ & $\begin{array}{l}\text { Mechanicnl Gazebo } \\
\text { Zero Energy Bulding }\end{array}$ & $\begin{array}{l}\text { Project B } \\
\text { - Resenteh Documentution } \\
\text { - Desigu (Severul Discussion } \\
\text { with Tean) }\end{array}$ \\
\hline $\begin{array}{l}\text { Euxir ununenl al } \\
\text { Technology }\end{array}$ & $\begin{array}{l}\text { Water Treatment } \\
\text { Green Wnil } \\
\text { Bionter in storm } \\
\text { Water Mlanggenent }\end{array}$ & $\begin{array}{l}\text { Project C } \\
\text { - Resench Documentation } \\
\text { - Design (Several Discussion } \\
\text { with Team) }\end{array}$ \\
\hline Dentistry & $\begin{array}{l}\text { Landscape Theenpy } \\
\text { Tooth Falry Walk }\end{array}$ & $\begin{array}{l}\text { Project D } \\
\text { - Rearnich Documentation } \\
\text { - Design (Sever al Discussion } \\
\text { with Team) }\end{array}$ \\
\hline
\end{tabular}

Figure 3: The Idea of Design through Multi-professional Input and Brainstorming 


\subsection{The Design Method and Outcomes}

The process of designing involved many disciplines working together to make one proposal that fulfill the resident needs and achieve goal of sustainability using green technology innovation and application. There are so many elements proposed in the park. The elements proposal mayrelate to multidiscipline of professional. For example, the architect proposed zero net energy building. The architect makes the design for the building. The civil engineer does a structure analysis while mechanical engineers decide the system that could be used for zero net energy buildings.

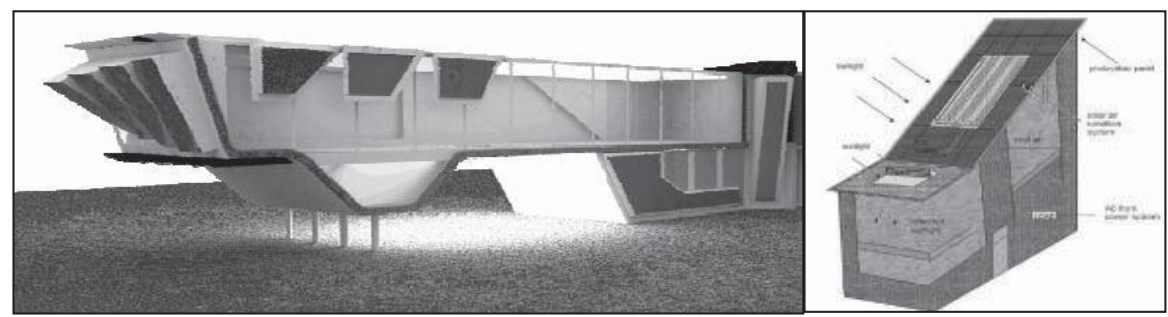

Figure 4: Example of Zero Net Energy Building Proposed by Architect and Mechanical System used in the Building (photovoltaic panel system)

The design for the site is drawn by built environment students with the consideration of the elements of green technology. All the professional plays their part doing a research before come out with design proposal. As explain in Fig 4. Civil Engineers, Mechanical Engineers and Environmental Technology and Dentistry proposed the suitable element for the lake and it must be agree by team members by doing several discussions with a proof of research and documentation. For example, Mechanical Engineers proposed mechanical gazebo and zero net energy building will be given name Project $B$. For the purpose of designing, zero energy building is not also involved mechanical engineers, it need other professional expertise to design the building and also civil engineers to do a structure analysis. Mechanical engineers job is to decide the system that will be used in the zero net energy buildings. (Rijal S. et. al, 2011).

\subsection{Conclusion}

Any effort towards making livable cities must be a concerted one with inputs from all professionals and stakeholders. Leadership is vital to ensure cohesion and to reach a common goal. In the areas of the built environment and provision of a facility for the people, the role of the Town Planner is vital to ensure that the Master Plan at State, Regional, District and Local levels provides for elements of livability for all current and future communities. Inthe design of these facilities, the elements that will help reduce theimpact of climate change must be incorporated and should be mandatory; what these elements are will need the input from all professionals and specialists. Green Technology is there to help us professionals in mitiga ting impacts of climate change, but there are also natural and cheaper solutions, such as the 
use of proper flora. Mitigating the impacts of climate change is a vital action towards the creation of livable cities. Given the growing interest in sustainable development along with concerns over global warming, a green technology design could be feasible in Tasik Biru Kundang, Kuang, Selangor. In fact, this project if developed, could serve as a model for the rest of the state. Attracting investment in renewable energy with other green technologies and demonstrating the competitiveadvantages ofgreendesign, operations and management.

\section{References}

Enrique Peñalosa Londono, 2001, "Park for Livable Cities: Lesson from a Radical Mayor”, Keynote Address, Urban Parks Institute's "GreatParks/GreatCities" Conference, New York.

Rijal S. etal, 2011, Planning Parkfor Livable Cities, Berita Perancang, Newsletter of Malaysian Institute of Planners, $1823-8874$.

Rijal S. et al, 2010, Sustainable Green Technology Innovation for Livable Cities, $1^{\text {st }}$ International Young Planners Forum, Kuala Lumpur.

The Economist Intelligence Unit (Aug 2012). "A Summary of the Livability Ranking and Overview". The Economist. Retrieved 2012-08-22. 